\title{
Talking TOD: Learning about Transit-Oriented Development in the United States, Canada, and the Netherlands
}

\author{
Dea van Lierop
}

School of Urban Planning, McGill University, Montréal, Canada

Suite 400, 815 Sherbrooke St. W. Montréal, Québec H3A 0C2

Tel.: 514-398-4058 Fax: 514-398-8376

E-mail: dea.vanlierop@mail.mcgill.ca

\section{Kees Maat}

Department of Urban and Regional Development, Delft Technical University, Delft, the Netherlands

Jaffalaan 9, 2628 BX Delft, Netherlands

Tel.:+31 (0) 152787640

E-mail: C.Maat@tudelft.nl

\author{
Ahmed El-Geneidy (corresponding author) \\ School of Urban Planning, McGill University, Montréal, Canada \\ Suite 400, 815 Sherbrooke St. W. Montréal, Québec H3A 0C2 \\ Tel.: 514-398-4058 Fax: 514-398-8376 \\ E-mail: ahmed.elgeneidy@mcgill.ca
}

For citation please use: van Lierop, D., Maat, K., \& El-Geneidy, A. (2017). Talking TOD: Learning about Transit-Oriented Development in the United States, Canada, and the Netherlands. Journal of Urbanism, 10(1), 49-62. 


\section{Acknowledgements}

The authors would like to thank the 13 urban planners, transportation professionals, and TOD managers who provided their time and input on which this paper has been based. We would also like to thank Angela Brinklow for providing us with the inspiration, framework, and contact information which allowed for the execution of this project, and Ana Tepavac for her assistance with the North American interviews. Finally, we would like to thank Social Sciences and Humanities Research Council (SSHRC) and the Netherlands Organization for Scientific Research (NWO) for the funding received for this research. 


\begin{abstract}
City and regional governments in North America and the Netherlands are implementing Transit-Oriented Development (TOD) policies to provide residents with accessible and compact communities that are socially, environmentally, and economically sustainable. Through 13 in-depth semi-structured interviews with planners and transportation professionals in the United States, Canada, and the Netherlands, this study attempts to identify the factors that practitioners in these regions determine to be essential for the postdevelopment success of TODs. Our analysis reveals that seven key elements contribute to the success of TOD which are approached differently by planners in the three regions. The study concludes by suggesting ways in which professionals could integrate land use and transportation projects based on planning for flexibility, accessibility, and collaboration.
\end{abstract}

Keywords: Transit-Oriented Development; land use; transportation; urban planning; semistructured interviews

\title{
Introduction
}

In North America and Europe, both city and regional governments are implementing Transitoriented development (TOD) policies to provide more socially, environmentally, and economically sustainable communities. This form of development is largely a reaction to the economically inefficient as well as environmentally and socially unsustainable automobiledependent suburban communities that characterized post-war planning. After the Second World War, the popularity and affordability of the automobile facilitated sprawling residential development and decentralization of employment locations. Infrastructure was developed to accommodate car dependent lifestyles, and public transit became increasingly limited and uneconomical in low-density areas. Residents relied heavily on their cars, resulting increased congestion on regional highways (Badoe and Miller 2000, Dunphy 2005, Easly 1992). One way 
to reduce the negative effects of urban sprawl is to build denser, mixed-use developments with the aim of decreasing reliance on the automobile, by making other modes more accessible and available (Cervero 2004, Chatman 2013, Samuelson 2009). Densifying urban areas around existing and new rail stations, and discouraging automobile use are expected to yield significant benefits for cities such increases in the use of sustainable travel modes for certain trips (Hofstad 2012, Renne and Wells 2004, Langlois et al. 2015). Also, such policy is expected to improve the social and economic prosperity of communities. However, with much of the city already built, the challenge is for planners to carefully develop these new urban environments while capitalizing on existing transportation infrastructure.

This study sets out to develop a better understanding of the process of TOD planning in the United States, Canada and the Netherlands. It questions what, in the opinion and experience of TOD-related professionals, are the most important factors influencing post-development TOD in their representative regions. The focus is on the opinions and experiences of practitioners because of their first-hand experience in planning TODs. Studies attempting to determine the factors contributing to effective TOD are useful to situate the context of this research. For example, Jacobson and Forsyth (2008) discuss good TOD practices based on analyses of seven TOD projects, and Thomas and Bertolini (2014) use a Meta-matrix of 11 case studies to determine critical success factors with regard to the TOD implementation process; they focus specifically on planning process, relationships with institutions, as well as policy. Although these studies provide useful suggestions, they do not directly include the experiences of planners and transport professionals - the individuals with hands-on experience. Therefore, the present study takes a different approach and determines the key elements influencing TOD in the abovementioned regions based on an analysis of 13 in-depth semi-structured interviews. First, we discuss the 
context of TOD in each geographic region. Next, we discuss how we prepared for the interviews and provide information about the themes presented in the interviews. We then discuss the results of the interviews and incorporate a discussion of the relevant literature to better frame the content of the interviews. Finally, we present the advice that TOD professionals have to offer for planners involved in planning future TODs.

\section{Context}

TOD planning involves integrating transport and land use planning in a way that promotes the use of public and active transportation over the use of the private car (Curtis, Renne, and Bertolini 2009). In the United States and Canada, TOD planning stems from the concept of New Urbanism ${ }^{1}$ (Burchell, Listokin, and Galley 2000) and focuses on increasing residential and commercial densities, mixed land uses, and pedestrian-friendly designs. Although variety in the form and content of New Urbanist communities exists (Trudeau 2013), a consistent goal of New Urbanism and TOD planning is to discourage auto use, and thereby focus on increasing transit ridership as well as walking and cycling trips (Boarnet and Compin 1999, Cervero and Kockelman 1997, Krizek 2003, Belzer and Autler 2002, Renne and Wells 2002).

In the Netherlands, TOD planning has its roots in the concept of Compact City ${ }^{2}$ (Alpkokin 2012). Yet, unlike the North American policies directly addressing auto use, Compact Cities are driven by policies encouraging economic development and urban containment that focus on densification both within cities and around rail stations. Moreover, even though the Compact City

\footnotetext{
${ }^{1}$ New Urbanism is a set of development practices to create more attractive, efficient, and livable communities. Features include a transit stop, retail businesses, public spaces, and amenities at its center such as gardens and public buildings (Burchell et al. 2000).

2 The European concept of the Compact City combats urban sprawl by indirectly targeting the negative consequences of auto-dependent neighbourhoods (Naess 2003, Naess et al. 2011, Nabielek 2012, Hofstad 2012, Raman 2010).
} 
approach includes social, economic, and environmental components, the focus of policies has been predominantly to strengthen the regional economy and foster economic growth (Nabielek 2012, Naess et al. 2011, Hofstad 2012).

In the United States, the concept of TOD often performs as a node, which although has been developed to be mixed-use, tends to be primarily mono-functional in practice (Boarnet and Compin 1999, Chatman 2013, Podobnik 2002). In the Netherlands TOD is often more effective in integrating multiple land uses and also frequently includes multi-modal transit hubs that provide frequent and reliable access to other TOD locations within the network (Geurs et al. 2012). The Canadian concept of TOD lies between that of the United States and the Netherlands. For example, even though planners in Vancouver, Canada have developed several individual TOD projects, they have ensured that the different developments are directly connected with the city's public transit network (Translink 2010). TOD planning in Vancouver tends to be similar to the Dutch approach in the way that each TOD is well-integrated into the wider transit system.

\section{Methods}

In this study we set out to learn what, in the opinion of practitioners, are the key elements influencing the implementation of TOD in the United States, Canada, and the Netherlands. Findings of this paper are derived from 13 semi-structured telephone and in-person interviews with transport planners, urban planners and TOD managers in these regions (Table 1). Initially we had set out to learn from TOD practitioners in several European countries, but because the overwhelming majority of the European TOD literature originated in the Netherlands, we narrowed the study to include only Dutch examples.

With this in mind, the first step that we took to prepare for the interviews was to review previous studies focusing on TOD in the three geographic regions. To identify what TOD scholars 
had determined to be important aspects influencing post-development TOD success, we searched for English-language, peer-reviewed articles published between 2000 and 2013 on the topic of land use and transportation integration that specifically analyse, discuss, or consider TOD (or related terms including rail-oriented development and traditional communities) and Compact City concepts. Literature was gathered through an extensive search utilizing Google Scholar, Science Direct, Taylor and Francis Online, Sage Publications, Web of Science and the Transportation Research Board archive. The terms searched included "Transit-Oriented Development," "New Urbanism," "Smart Growth," "land-use and transportation," "transit villages," "transit communities," and "compact city." Additional relevant literature was selected by searching the references cited in each paper. The majority of papers that surfaced through the search were from North America, and almost all were from the United States with the exception of a literature review by the regional transportation authority for Vancouver, Canada, and several studies from Asia, Australia, Scandinavia, and Western Europe. However, because we decided to focus on learning about TOD in the United States, Canada, and the Netherlands, studies conducted outside of these regions were not included. The search process led to the review of approximately 40 papers that analysed various aspects of TOD. The most commonly discussed dimensions of TOD were selected and classified into seven categories: physical design, transportation, environment, social/community, economy, collaboration, and accessibility. These themes were used to frame participant interviews and a discussion of the scholarly discourse on these topics is presented later in the paper in order to contextualize the interview findings.

In addition to setting the framework for the content of the interviews, the review of the literature also helped us select the geographic locations where the interviews would take place. The overwhelming majority of the TOD literature focuses on the United States, with particular 
developments in New Jersey, California, Texas, Oregon, and Virginia often being recognized for their success (Cervero 2004, Dunphy and Porter 2006, Renne 2008, 2009, Bae 2002, Niles and Nelson 1999). Invitations to participate in the study were sent to TOD managers, urban planners, and transportation professionals in these regions and TOD professionals in New Jersey, San Diego, San Francisco, and Dallas responded positively and were later included in the study. Our requests in Arlington and Portland were not returned and therefore could not be included in the study. Although interviews with TOD professionals in Portland and Arlington would enrich this study further, the geographic and contextual variation in the other locations provides insight into TOD across the United States. In Canada, interviewees were chosen in Vancouver because of the City's current focus on TOD (Translink 2010), and because the Joyce/Collingwood TOD has become internationally renowned (Davison 2011, Newman 2007). Interviews were also requested in Toronto, but were denied. As previously mentioned, the Netherlands was included in this study as the overwhelming majority of the European TOD literature stems from this country; many researchers in this area are working on analyses of a comprehensive program for spatial development and public transport the Dutch province of South Holland (Balz and Schrijnen 2009).

Individuals representing TODs in a variety of settings were chosen to be interviewed. In the United States and Canada, interviewees represented specific TODs, while in the Netherlands interviewees were chosen based on their involvement with an important TOD and rail development project in the country's highest populated region (Geurs et al. 2012). In the case of San Diego, Vancouver, and the Dutch province of South-Holland, more than one person was contacted per region, as the first person interviewed recommended that we also speak to another person in the region. Interviewees were contacted by telephone and email to schedule interview times. In total, eight formal, semi-structured telephone interviews were conducted at times specified by the 
participants. They were not recorded, but handwritten notes were taken during the interview. All of the American and Canadian interviews were conducted over the phone, as well as one Dutch one. In addition to phone interviews, six in-person semi-structured interviews were conducted at several planning offices throughout the Netherlands. A total of 13 semi-structured interviews are included in this study: seven were with participants in North America and six with planning and transport professionals in the Netherlands. Table 1 includes a list of professionals interviewed for the study. Although the interviewees' official titles differ from one another, these individuals were included as they were responsible for similar aspects of the TOD planning process. 
Table 1: List of interviewees

\begin{tabular}{|c|c|c|c|}
\hline Name & Title & City/State/Region & TOD \\
\hline Baker, Vivian & $\begin{array}{l}\text { Assistant Director of New Jersey } \\
\text { Transit (NJT) }\end{array}$ & $\begin{array}{l}\text { New Jersey: United } \\
\text { States }\end{array}$ & $\begin{array}{l}\text { Morristown, South } \\
\text { Orange, Rahway }\end{array}$ \\
\hline Baldwin, Susan & $\begin{array}{l}\text { Senior Regional Planner with } \\
\text { SANDAG }\end{array}$ & $\begin{array}{l}\text { San Diego, California: } \\
\text { United States }\end{array}$ & $\begin{array}{l}\text { Rio Vista West, } \\
\text { Uptown District, } \\
\text { America Plaza }\end{array}$ \\
\hline Bragado, Nancy & $\begin{array}{l}\text { Program Manager in Development } \\
\text { Services, Planning Division with the } \\
\text { City of San Diego }\end{array}$ & $\begin{array}{l}\text { San Diego, California: } \\
\text { United States }\end{array}$ & $\begin{array}{l}\text { Rio Vista West, } \\
\text { Uptown District, } \\
\text { America Plaza }\end{array}$ \\
\hline de Visser, Gert & $\begin{array}{l}\text { Project Leader of Land Use } \\
\text { Development, StedenbaanPlus }\end{array}$ & $\begin{array}{l}\text { South Holland (Zuid- } \\
\text { Holland): Netherlands }\end{array}$ & StedenbaanPlus \\
\hline Gelissen, Herman & Program Director, StedenbaanPlus & $\begin{array}{l}\text { South Holland (Zuid- } \\
\text { Holland): Netherlands }\end{array}$ & StedenbaanPlus \\
\hline Gordon, Michael & $\begin{array}{l}\text { Senior Central Area Planner with } \\
\text { City of Vancouver }\end{array}$ & $\begin{array}{l}\text { Vancouver, British } \\
\text { Columbia: Canada }\end{array}$ & Collingwood Village \\
\hline Jansen, Barend & $\begin{array}{l}\text { Policy Advisor with the Metropolitan } \\
\text { District of Haaglanden }\end{array}$ & $\begin{array}{l}\text { The Hague and } \\
\text { Rotterdom, South } \\
\text { Holland (Zuid-Holland): } \\
\text { Netherlands }\end{array}$ & $\begin{array}{l}\text { StedenbaanPlus, } \\
\text { Haaglanden region }\end{array}$ \\
\hline Johnson, Doug & $\begin{array}{l}\text { Senior Transportation Planner with } \\
\text { Metropolitan Transportation } \\
\text { Commission (MTC) }\end{array}$ & $\begin{array}{l}\text { San Francisco, } \\
\text { California: United States }\end{array}$ & $\begin{array}{l}\text { Fremont, Hayward, } \\
\text { Berkeley }\end{array}$ \\
\hline Schrijnen, Joost & $\begin{array}{l}\text { Spatial Management Consultant, the } \\
\text { Rotterdam Area }\end{array}$ & $\begin{array}{l}\text { Rotterdam, South } \\
\text { Holland (Zuid-Holland): } \\
\text { Netherlands }\end{array}$ & $\begin{array}{l}\text { StedenbaanPlus, } \\
\text { Rotterdam region }\end{array}$ \\
\hline $\begin{array}{l}\text { Termorshuizen, } \\
\text { Jan }\end{array}$ & $\begin{array}{l}\text { Transportation and Mobility Expert, } \\
\text { the Hague Region }\end{array}$ & $\begin{array}{l}\text { South Holland (Zuid- } \\
\text { Holland) }\end{array}$ & $\begin{array}{l}\text { StedenbaanPlus, The } \\
\text { Hague region }\end{array}$ \\
\hline $\begin{array}{l}\text { van Staalduine, } \\
\text { Klaas }\end{array}$ & $\begin{array}{l}\text { Project Leader in Network } \\
\text { Development and Rail, } \\
\text { StedenbaanPlus }\end{array}$ & $\begin{array}{l}\text { South Holland (Zuid- } \\
\text { Holland) }\end{array}$ & StedenbaanPlus \\
\hline Walker, Lyle & $\begin{array}{l}\text { Senior Planner, Transportation and } \\
\text { Land Use with Translink }\end{array}$ & Vancouver & Collingwood Village \\
\hline Wierzenski, Jack & $\begin{array}{l}\text { Director of economic Development } \\
\text { with DART }\end{array}$ & Dallas, Texas & Mockingbird Station \\
\hline
\end{tabular}

\section{Results}

Interviewees were asked a series of questions about the TOD planning process in the context of the geographic region of the TOD they represented. More specifically, they were asked to discuss their goals and approaches, with regard to each of the themes identified in the literature. In addition, the interviewees were asked what, in their opinion, are the key elements of a successful TOD. Finally, they were asked whether they had any advice for TOD professionals involved in 
the development of future TODs. To ensure consistency, each interviewee was presented with the following definitions:

- Physical design refers to elements of the built environment that planners and transportation professionals consider being essential for the success of TOD.

- Transportation not only refers to the rail network, but also recognizes the importance of planning for access and egress modes.

- Environment refers to policies and design elements that improve quality of life by protecting and improving environmental standards.

- Social encompasses the need and awareness to plan a community and transportation network that is accessible for people of different ages, abilities, social backgrounds, and lifestyles.

- Economy recognizes that the success of TOD depends partially on its financial successes.

- Collaborations refers to the need for collaboration between stakeholders, and big-picture, network-focused planning.

- Accessibility refers to generating a system of residential, commercial, and transportation services that allows commuters to access facilities they wish to reach.

These themes were used to shape the interviews, and are discussed within the context of the relevant literature in the next section. Although, specific aspects of the themes are interconnected, each one is discussed in a different subsection below.

\section{Physical Design}

The first questions that we asked the interviewees had to do with the physical design of the TOD they represented. We chose to start by discussing the physical design as it is a major determinant of TOD success in the literature. For example, density, mixed-use, and a quality pedestrianfriendly environment are consistently identified as key elements of the physical design necessary for the success of TOD (Belzer and Autler 2002, Calthorpe 1993, Cervero, Ferrell, and Murphy 
2002, Cervero and Kockelman 1997, Chatman 2013, Handy 2001, Krizek 2003, Ohland 2001, Renne 2009, Samuelson 2009).

In the literature there is a strong emphasis on the importance of providing quality pedestrian and cycling environments at TOD locations (Belzer and Autler 2002, Calthorpe 1993, Cervero, Ferrell, and Murphy 2002, Cervero and Kockelman 1997, Chatman 2013, Handy 2001, Krizek 2003, Ohland 2001, Renne 2009, Samuelson 2009, Wayne 2007). In the Netherlands TOD catchment areas tend to be larger than in other regions due to the fact that a high number of access and egress trips to the main transit hub are made by bicycle (Balz and Schrijnen 2009). The physical design of TODs should be developed to accommodate non-motorized access and egress modes and be assessed by using indicators that include street width, grid pattern, block size, connections, and amount and location of parking (Renne 2009, Cervero and Kockelman 1997). TOD scholars have made clear that physical designs should promote vibrant environments, have diverse functions, and include architectural and urban design features that emphasize both vertical and horizontal development (Renne 2009, Belzer and Autler 2002, Cervero and Kockelman 1997).

Similar to the results presented in the literature, interviewees assessed the success of the physical design of TODs by using indicators that include street width, grid pattern, block size, connections, and amount and location of parking. Three American and one Canadian TOD professional emphasized that future TOD developers should be willing to invest in urban design to create safe and vibrant active transport networks for people of all ages, socio-economic statuses, and abilities. ${ }^{3}$

\footnotetext{
${ }^{3}$ Johnson, D. (Senior Transportation Planner with Metropolitan Transportation Commission) In discussion with the authors, June 2013.

Baker, V. (Assistant Director of New Jersey Transit) In discussion with the authors, June 2013.

Gordon, M. (Senior Central Area Planner, City of Vancouver) In discussion with the authors, June 2013.

Wierzenski, J. (Director of Economic Development, DART) In discussion with the authors, June 2013.
} 
With regard to facilities at stations, two American planners suggested including temporary office spaces (short-term rental spaces) as a means of improving station attractiveness. ${ }^{4}$ In the Netherlands, this is already a reality, calling the spaces "Seats2meet" (Seats2Meet 2013), where high-tech meeting spaces are available for rental by different firms to conduct business at the transit station..$^{5}$

Nancy Bragado, Program Manager in Development Services with the City of San Diego, expressed the need for universally accessible urban design by stating "at the end of the day, TOD should take into account the needs of many different people and respect all the elements of good basic planning." "Susan Baldwin, Senior Regional Planner with SANDAG, similarly expressed that accommodating all ages and socio-economic statuses translates to a mix of housing types with respect to physical design. Baldwin, as well as another American and a Canadian planner made clear that it is necessary to have a good mix in terms of commercial and residential developments in a TOD that are designed to resemble the buildings in the surrounding neighbourhoods. ${ }^{7}$

One important idea that is not emphasized in the literature but stressed by Michael Gordon, Senior Central Area Planner for the City of Vancouver, Canada is the need to resist erasing or attempting to re-write the history of the land where new TODs are built. Other planners also made clear that providing TODs with an identity that is relevant to its geographic location is important for the success of a development. On brownfield sites, like is commonly the case in Vancouver,

\footnotetext{
${ }^{4}$ Baker 2013

Baldwin, S. (Senior Regional Planner with SANDAG) In discussion with the authors, June 2013.

${ }^{5}$ Schrijnen, J. (Spatial Management Consultant for Rotterdam Area, the Netherlands) In discussion with the authors, June 2013.

${ }^{6}$ Bragado, N. (Program Manager in Development Services, Planning Division, City of San Diego) In discussion with the author June 2013.

${ }^{7}$ Baldwin 2013, Bragado 2013, and Gordon 2013
} 
this could be reached by giving tribute to an area's history, ${ }^{8}$ whereas on greenfield sites, a new identity could be created through innovative urban design with an emphasis on place making. ${ }^{9}$

To measure the success of the physical design of a TOD, all of the North American interviewees reported using both land use density as well the number of people who walk to the rail station. Included in their definitions of density was the number of square metres of office space, variety of development, and number of housing units. ${ }^{10}$ Similar ideas are found in the literature where it is claimed that medium and high-density ${ }^{11}$ developments are more likely to contribute to the success of TODs as they can encourage people to walk, cycle, or use transit (Bernick and Cervero 1997, Ewing, Pendall, and Chen 2002, Frank and Pivo 1994, Kuzmyak and Pratt 2003, Moudon et al. 1997, Newman and Kenworthy 1999, 2006, Krizek 2003, Chatman 2008).

In the Netherlands, the physical design discourse takes on a more general tone and refers to the quality of life that the urban design of a TOD can provide. Planners are concerned with developing stations that are both origins and destinations and making them attractive places to live and work. For example, Barend Jansen emphasized the need to make attractive, dense, and urban pre-war style neighbourhoods. Similarly to TOD development in North America, there is a focus on creating a design that encourages active transportation. ${ }^{12}$

With regard to parking, the approach varies between the Netherlands and North America. In the Netherlands, a major goal of TOD is to provide attractive, well-integrated, and safe parking facilities for bicycles, automobiles, and taxis. For example, Joost Schrijnen, Spatial Management

\footnotetext{
${ }^{8}$ Gordon 2013

${ }^{9}$ Bragado 2013

${ }^{10}$ Bragado 2013, and

Johnson, D. (Senior Transportation Planner with Metropolitan Transportation Commission) In discussion with the authors, June 2013.

Walker, L. (Senior Planner, Transportation and Land Use, Translink) In discussion with the author, June 2013.

11 There are a number of measures of density, with the consensus being a minimum of 10 to 30 dwelling units per acre (Boarnet and Compin 1999, Calthorpe 1993, Cervero 2004).

12 Jansen, B. (Policy Advisor with Metropolitan District of Haaglanden) In discussion with the authors, June 2013.
} 
Consultant for the Rotterdam Area, supported the development of well integrated park and ride facilities in TOD hubs by stating that "the Netherlands is a car-oriented region, and you have to accept that." The point that Schrijnen made is that if you want people who cannot live close to a rail station to take a train, you must provide drivers with parking that is close to and well-integrated into the physical environment of the TOD. The literature from the Netherlands supports the idea of developing ample space for parking by emphasizing the regional context of TOD and how the availability of parking around transit nodes is positive because it encourages hinterland residents to use transit (Nabielek 2012, van Wee and Maat 2003).

\section{Transportation}

In the literature, increasing transit ridership and the use of active modes of transportation is cited as the primary measures of TOD success in terms of transportation (Cervero and Kockelman 1997, Cervero 2004, Renne 2009, Renne and Wells 2004, Chatman 2013, 2008, Handy 2001, Belzer and Autler 2002). All of the interviewees also revealed that the most important TOD success indicator in their region was an increased number of non-auto trips. This was specifically prominent for the interviews taking place in North America, where the mode share of active transportation is lower than that of the Netherlands. Because of the lower percentages of pedestrians and cyclists in the United States and Canada, interviewees in these regions said that they were specifically focusing on ways to increase the number of pedestrians and cyclists (Translink 2010). ${ }^{13}$ All of the interviewees agreed that increases in active transportation for single mode trips as well as an access mode for transit are indications of post-development TOD success. In addition, three American and one Canadian planner not only determined the well-being of a TOD by the total number of

\footnotetext{
${ }^{13}$ Baker 2013, Baldwin 2013, and Gordon 2013
} 
transit riders, but also by the number of choice riders, as opposed to captive riders, using the transit service. $^{14}$

Similarly to the approach of the North American interviewees included in the study, Dutch planners continuously worked to improve pedestrian and cyclist access to train stations in TOD areas. However, all of the TOD professionals in the Netherlands stated that the primary goal when developing TOD was to decrease commuters' overall travel time. One way that this goal is being reached is StedenbaanPlus's ${ }^{15}$ plan to increase ridership by intensifying the frequencies of trains from four to six per hour. ${ }^{16}$ However, although the literature states that increases in ridership are commonly used to calculate the success of a TOD (Geurs et al. 2012, Scheurer and Kroen 2005, Maat 2001, Hofstad 2012), when Dutch planners were asked whether TOD success should be determined by its achievements using the quantity of boardings and alightings, two stated that they prefer to base overall success on the quality of life that TOD inhabitants and users experience. ${ }^{17}$ The StedenbaanPlus project demonstrates that unlike the North American emphasis on creating an urban village feeling where proximity dictates development, Dutch TODs focus on providing access to high frequency trains available at multi-modal transit hubs. Schrijnen stressed this notion by stating, "public transit is the backbone of the network."

\section{Environment}

\footnotetext{
${ }^{14}$ Baker 2013, Baldwin 2013, Johnson 2013, and Gordon 2013

${ }^{15}$ StedenbaanPlus is a comprehensive program for spatial development and public transport the Dutch province of South Holland.

${ }^{16}$ de Visser, G. (Project Leader of Land Use Development, StedenbaanPlus) In discussion with the authors, June 2013.

Gelissen, H. (Program Director, StedenbaanPlus) In discussion with the authors, June 2013

Schrijnen 2013

van Staalduine, K. (Project Leader in Network Development and Rail, StedenbaanPlus) In discussion with the authors, June 2013

${ }^{17}$ Termorshuizen, J. (Transportation and Mobility Expert, The Hague Region) In discussion with the author, June 2013., and van Staalduine 2013
} 
The success indicators assessing physical design and transportation dominate both the literature and interviews. The literature draws inconsistent conclusions on the topic of the environment and it is worth noting that the idea of conserving green space differs between North America and the Netherlands (van Wee and Maat 2003, Nabielek 2012, Naess et al. 2011, Hofstad 2012); in North America, the concept refers to safeguarding and protecting a particular piece of land, while in the Netherlands the focus is often on conserving a particular amount of land regardless of location. The literature discusses the "balancing principle," which involves a compensation for loss of green space that varies in practice for each municipality (Hofstad 2012).

When the TOD representatives were asked to outline any specific environmental goals, two Dutch planners warned that framing land use and transportation development through an environmentally focused agenda is not helpful for development. In the United States Jack Wierzenski, Director of Economic Development with Dallas Area Rapid Transit (DART), had a more positive response and emphasized the importance of ensuring that environmental sustainability is a prominent aspect featured in every TOD plan. Other American TOD professionals emphasized the importance of providing enough public space, such as parks. ${ }^{18}$

In California, the Clean Air Act is driving the environmental focus of development. The literature supports these goals, particularly the provision of parks and recreational space (Renne and Wells 2002, Belzer and Autler 2002, Podobnik 2002, Renne et al. 2005). In addition, Renne et al. (2005) included the amount of air pollution, measured through Air Pollution Index reports, and consumer gasoline consumption, measured in gallons. However, although several environmental issues were discussed in the interviews, the lack of consistency and detail

\footnotetext{
${ }^{18}$ Bragado 2013, and Baldwin 2013
} 
demonstrates that, to our surprise, the environment is not a major issue for TOD planning in any of the three regions.

\section{Social}

The literature predominantly addresses the social aspects of TOD by discussing the importance of social housing. In the North American literature, there is a greater focus on affordable housing, the diversity of housing types, and a sense of community, which are all cited as important components of a neighbourhood (Calthorpe 1993, Renne and Wells 2002, Podobnik 2002, Lund 2006). Affordable housing is particularly important in a TOD because lower-income passengers often represent the majority of transit users (Dunphy, Myserson, and Pawlukiewicz 2003, Tumlin and Millard-Ball 2003, Podobnik 2002, Lund 2006).

All of the interviewees stated that the inclusion of affordable housing should be a key component in the planning of any TOD, and two interviewees emphasized the importance of planning for different people with varying socio-demographic backgrounds. ${ }^{19}$ Planners in the United States cited community involvement as a priority and a necessary component of TOD to warrant successful implementation. For example, Vivian Baker, Assistant Director of New Jersey Transit, stated that a goal of the New Jersey Transit Villages Initiative is to "inform, educate, and communicate" with TOD residents in the effort to ensure that people know the importance of living in TOD and that they feel they are a part of a community. However, while fostering a sense of community is not explicitly on the agenda for Dutch planners, it is also not ignored. More specifically, a Spatial Management Consultant in the Rotterdam Area revealed that the Dutch

\footnotetext{
${ }^{19}$ Johnson 2013 and Gordon 2013
} 
approach does not place social goals at the forefront of planning but rather expects social benefits to be a product of good planning. ${ }^{20}$

\section{Economy}

The economic goals of planners from North America and the Netherlands differ due to their spatial contexts. In North America, the approach is primarily local and centred on the neighbourhood level; the literature focuses on how proximity to transit increases the consumer base and the labour supply resulting in higher property values (Belzer and Autler 2002, Samuelson 2009, Cervero 2004). In the Netherlands planners have a more regional perspective with respect to their economic goals; their primary concern is to ensure that major cities do not compete when it comes to job opportunities, but rather benefit economically from each other through decreasing travel times between hubs (Balz and Schrijnen 2009). Additionally, jobs should be located near transit stations, and focus should be placed on the economic goals behind the decision of developing job opportunities around nodes (Meurs and Haaijer 2001, Naess et al. 2011, Naess 2003, van Wee and Maat 2003, Headicar 2003, Nabielek 2012, Keller et al. 2011, Geurs et al. 2012). Similar claims are made in the North American literature, which often suggests that commerce be located within a quarter of a mile of transit stations (Guerra and Cervero 2013).

Findings from the literature are reflected in the interviews with planners. For example, in Vancouver, one way that the economic success of TODs is determined is by creating revenue opportunities primarily through retail, and ensuring a good mix of local and big businesses. ${ }^{21}$ Additionally, in New Jersey, Baker, stated that the growth of grant money can also be used as an

${ }^{20}$ Schrijnen 2013

${ }^{21}$ Gordon 2013 
indicator of the success of TOD since the more TOD-specific funding is available, the more emphasis is placed on TOD, signifying its growing popularity and importance. Furthermore, other TOD professionals in the United States, Canada and the Netherlands, stated that a measure of economic success should include the number of jobs produced and the number of housing units. ${ }^{22}$

\section{Collaboration}

The discourse on collaboration includes the process of policy implementation, as well as managing expectations. The literature on this topic discusses the need for partnerships and collaborations between stakeholders, emphasizes the need to align goals with interventions, and warns against developing goals that are the result of arbitrary policies (Boarnet and Compin 1999, Renne and Wells 2002, Ohland 2001, Samuelson 2009, Cervero 2004, Belzer and Autler 2002). For example, Curtis, Renne, and Bertolini (2009) discuss the roles of various stakeholders emphasizing the complexity of coordinating land use and transport planning with various developers, investors and users.

Similarly to the literature, interviewees discussed the need for TOD policies to be made with specific goals in mind. According to Lyle Walker, Senior Planner with Translink, in Vancouver, TOD will function only when the municipal development plan meets the goals of the region. Another concern for planners and transportation professionals in North America is the need to manage expectations, realizing that successful TOD takes time, and therefore it is important to be patient with the development process. ${ }^{23}$ Consequently, there is the need to make sure that TOD is successful both in the short-term and the long-term. In other words, planners must be flexible

\footnotetext{
${ }^{22}$ Bragado 2013, Termorshuizen 2013, and Walker 2013

${ }^{23}$ Wierzenski 2013 and Bragado 2013
} 
and willing to make compromises to accommodate the changes in demographics, technology, and land use over time.

\section{Accessibility}

As with the majority of the themes listed, North American and Dutch approaches to accessibility vary in terms of scale and the goals of development. Accessibility is defined as a measure of potential opportunities for interaction (Hansen 1959) and is understood in terms of providing people with access to as many opportunities as possible by different modes (El-Geneidy and Levinson 2006). Interviewers defined accessibility to the interviewees as the generation of a system of residential, commercial, and transportation services that allows commuters to access the facilities they wish to reach. When interviewees were asked to define their accessibility-related goals specific to the TOD they represented, two Dutch planners responded by stating that the success of a TOD should be determined by the level of accessibility it provides to transit users. ${ }^{24}$ Schrijnen emphasised the goal of developing polycentric and metropolitan regions that include housing and commercial uses at different TOD locations that serve as both origins and destinations. However, he made clear, that this goal could not be achieved in the short-term, but that it should be a priority for long-term planning. In addition, all of the Dutch planners said that TOD should focus on network accessibility in terms of multimodality. In other words, TOD planning in the Netherlands works towards ensuring that all modes, including cars, have access to the rail network. In contrast, all of the North American planners discussed accessibility within individual TODs, and only planners in Vancouver mentioned the importance of the network. In addition, two

\footnotetext{
${ }^{24}$ Schrijnen 2013 and Gelissen 2013
} 
North American TOD professionals also referred to what they called "financial accessibility" which they defined as the process of ensuring that no resident will be priced-out of the market. ${ }^{25}$

The 13 semi-structured interviews with TOD professionals and the discussion of the literature reveal that while some "good practices" are already well-established in previous TOD literature, others are not. In addition, the interviews made clear that the planning process continues to be forward thinking with many planners concentrating on how to improve existing and future TODs. However, TOD professionals in San Francisco and San Diego expressed their concerns about plans that are developed based on arbitrary goals rather than on an assessment of the failures and successes of past projects, and therefore suggested that planners take the time to reflect and assess the communities that they have planned before continuing to generate future TODs. ${ }^{26}$ Table 2 provides a summary of practitioners' advice for successful post-development TOD planning that is based on their hands-on experience.

Table 2: Practitioners' advice

25 Johnson 2013 and Baldwin 2013

${ }^{26}$ Johnson 2013 and Bragado 2013 


\begin{tabular}{|c|c|}
\hline \multicolumn{2}{|r|}{ PRACTITIONERS' ADVICE } \\
\hline Physical design & $\begin{array}{l}\text { - } \quad \text { Build dense, mixed-use TODs with safe and attractive public realms } \\
\text { - } \quad \text { Develop a multi-functional and attractive transit station } \\
\text { - } \quad \text { Develograte the TOD into the surrounding neighbourhoods } \\
\end{array}$ \\
\hline Transportation & $\begin{array}{l}\text { - } \quad \text { Achieve a high mode share of active transportation users } \\
\text { - } \quad \text { Ensure high frequency of transit service } \\
\text { - } \quad \text { Design high quality facilities and vehicles } \\
\text { - Measure success based on increases on overall quality of life }\end{array}$ \\
\hline Environment & $\begin{array}{l}\text { - } \quad \text { Conserve existing green space } \\
\text { - } \quad \text { Develop quality, attractive, and safe public spaces } \\
\text { - } \quad \text { Measure air quality and consumer gas consumption to assess TOD }\end{array}$ \\
\hline Economy & $\begin{array}{l}\text { - } \quad \text { Gain revenue from businesses } \\
\text { - } \quad \text { Determine TOD success by increases in TOD grant money } \\
\text { Base success on the number of jobs produced and the number of residential } \\
\text { units inhabited }\end{array}$ \\
\hline Collaborations & $\begin{array}{l}\text { - Create collaborations between stakeholders } \\
\text { - Develop policies with specific goals in mind } \\
\text { - Allow for flexibility to accommodate for changes in demographics, } \\
\text { technology, and land use over time }\end{array}$ \\
\hline Accessibility & $\begin{array}{l}\text { - } \quad \text { Ensure that every TOD is both an origin and a destination } \\
\text { - } \quad \text { Focus on multimodality } \\
\text { - } \quad \text { Plan for populations with different needs }\end{array}$ \\
\hline
\end{tabular}

\section{Discussion}

The final interview question asked the TOD professionals about the advice that they would give their colleagues to develop successful future TODs. Although responses varied and included specific elements from each of the seven themes discussed above, the overarching advice was that planners should plan for flexibility, accessibility, and collaboration.

\section{Plan for flexibility}

The theme of planning for flexibility arose due to the need for planners to be able to adjust land use development and transportation systems to changes in the financial and political economy. Planners in the United States and the Netherlands emphasized the need to adjust the physical design and transportation options at TODs in accordance with changes in demand and explained that these variations were not always the result of demographic changes, but also of unstable financial systems that caused the 2008 financial crises and resulted in unexpected financial losses 
for many developers. As a result of these unanticipated changes, nearly all of the interviewees said that the most important advice they would give their colleagues would be to plan for economic flexibility as well as technological and land use flexibility.

Economic flexibility allows planners to adjust land use and transportation planning according to changes in available finances. For example, Baldwin stressed the importance of planning and executing TOD in phases, allowing for flexibility dependant on market demand. She also suggested allowing for flexible short- and long-term budgeting to ensure that plans remain financially feasible in the long-term, and stated that developments must be compatible with the current market to avoid the risk of becoming obsolete. ${ }^{27}$ Wierzenski also emphasized this point, stating the futility of forcing development on a market that does not exist.

Technological and land-use flexibility allows planners to change the physical design of some areas in a TOD, based on developments in technology and changes in the needs of the population. According to four different American planners, this form of flexibility strengthens both the short- and long-term viability of TOD. ${ }^{28}$ The idea of planning for unpredictable change was particularly stressed by Doug Johnson, who stated "things are happening now that planners could never have anticipated." It is therefore necessary to be clear from the beginning what the TOD will look like and how it will function, using a system that preserves good design and is not too rigid, allowing for flexibility. ${ }^{29}$ Walker and Baldwin elaborated on this notion stating that planners and transportation professionals must recognize that each TOD is location-dependent and there is no "one size fits all, cookie-cutter approach." In other words, each TOD has its own specific needs that may change over time. Flexibility in terms of expectations is also integral to the discussion;

\footnotetext{
${ }^{27}$ Baldwin 2013

${ }^{28}$ Baker 2013, Baldwin 2013, Bragado 2013, and Johnson 2013

${ }^{29}$ Baker 2013 and Bragado 2013
} 
planners must manage their expectations and realize that creating a successful TOD takes time. It is therefore, necessary to be patient with the development process. ${ }^{30}$ Transportation professionals had advice specifically relating to bus transit. For example, Walker cautioned against focusing only on rail-based development, encouraging planners to consider bus corridors. Baker advocated for bus transit, specifically development around Bus Rapid Transit (BRT) stations or creating BRT connections to rail. Walker also identified flexibility with respect to service, such as increasing or decreasing the number of busses or shuttles. TOD professionals also had advice about flexibility in terms of land use and infrastructure. For example, four planners in the United States and Canada identified the need to be flexible in the transit plan both in form and in use, such as allowing for the conversion of car parking to a bicycle lane or being flexible about the location of a bus route. ${ }^{31}$ For example, Bragado identified shared office spaces as potential station facilities that would increase the station's attractiveness. Others spoke about the need for community spaces such as public parks and libraries. ${ }^{32}$ Only Gordon was not completely convinced of prioritizing flexibility in planning; he cautioned against it, stating that the ambiguity of what a business location could be (e.g. nightclub vs. flower shop) could negatively influence property values and negatively affect the residents.

\section{Plan for accessibility}

In the Netherlands all of the interviewees mentioned the importance of ensuring multi-modal regional connectivity and explained that these concepts had been included in the current TOD plans. Similarly, in the United States and Canada, the majority of planners also stressed the

\footnotetext{
${ }^{30}$ Bragado 2013 and Walker 2013

${ }^{31}$ Baldwin 2013, Bragado 2013, Johnson 2013, and Walker 2013

32 Bragado 2013, Johnson 2013, and Gordon 2013
} 
importance of integrated regional TOD planning. However, in North America, there is a stronger history of isolated pockets of development such as the suburban neighbourhood that can only be reached by car, and consequently, the notion of regional connectivity is still somewhat illusory although planners agree that it is paramount. Johnson emphasized that TODs should only be developed in existing neighbourhoods or cities and that isolation simply does not work. Planners in Canada also explained their integrated approach and made clear that TODs must be planned as part of a regional network. An important difference between how North America and the Netherlands approached accessible planning is that in the United States and Canada the interviewees generally considered accessible planning to be synonymous with inclusionary planning. However, in the Netherlands, the concept of accessible planning focused more generally on decreasing travel times with the goal of increasing employer activities and positively influencing the overall economy. ${ }^{33}$ While these interpretations of accessibility have resulted in the development of different goals in North American and European TOD planning, it is clear that in both cases planners are dedicated to increasing overall access to residential, commercial, and transit facilities services.

\section{Plan for collaboration}

All of the interviewees strongly encouraged collaborative planning with the goal of sharing of data and transferring knowledge. To make this possible, they identified the need to develop a common language between planners, designers, and transportation professionals. The notion of integration and collaboration also transfers to the broader community. Three American TOD professionals emphasized that without the involvement of the residents, TOD has less chance of success. ${ }^{34}$ These

\footnotetext{
${ }^{33}$ Schrijnen 2013 and van Staalduine 2013

34 Baker 2013, Bragado 2013, and Johnson 2013
} 
interviewees also emphasized that collaborative planning is essential for developing socially equitable TODs, and their advice focused on creating inclusionary policies such as affordable housing, community projects, building public spaces (including facilities available to share), and ensuring that the original residents do not get priced out of the market. ${ }^{35}$ In addition, collaboration also refers to developing supportive planning tools that make the development plans more finically predictable for those involved (Venner and Ecola 2015).

\section{Limitations and conclusion}

Findings from interviews with 13 TOD professionals and a discussion of the relevant literature suggest that the approaches to TOD planning in the United States, Canada, and the Netherlands have many similarities but are also geographically specific given the cultural context of each development. Limitations of this study include the number of interviews, and the fact that not all of the TOD professionals that we contacted accepted to be part of the study. This is especially true in Canada, where only one city was included in the study. Future research should allocate more time to recruitment.

Differences between the American, Canadian, and Dutch approach to TOD planning include the fact that with regard to physical design, North American planners focus on urban design features whereas in the Netherlands it is on improving the overall quality of life by enhancing the urban environment. Although the results may be similar, planners in the regions approach physical design from different angles. To improve mobility in and to TODs North American planners focus heavily on improving active transport networks, whereas in the Netherlands they focus on developing multi-modal hubs and short travel times between rail communities. Another major

\footnotetext{
${ }^{35}$ Baker 2013, Bragado 2013, and Johnson 2013
} 
difference between the regions was that while the American TOD professionals stated the importance of developing a community, Dutch planners stated that a TOD's social benefits should come as a result of good physical, transportation, and economic planning. However, with regard to the environment, planners in each region agreed that it was not a primary goal, but rather that environmental benefits were expected to result from TOD initiatives.

The final interview question provided invaluable advice from TOD professionals to future TOD planners. Advice about planning for flexibility, accessibility, and collaboration is useful for planners to develop future TODs. And, although the advice from planners was given in the context of discussing TOD, these concepts are not unique to this type of development and generally define good planning practice. Johnson reiterated this idea by stating that TOD "can just be good planning."

\section{References}

Alpkokin, P. . 2012. "Historical and critical review of spatial and transport planning in the Netherlands." Land Use Policy 29 (3 ):536-547.

Badoe, D., and E. Miller. 2000. "Transportation and land-use interaction: empirical findings in North America, and their implications for modeling " Transportation Research Part D: Transport and Environment 5 (4):235-263.

Bae, C. 2002. "Orenco station, Portland, Oregon: A successful transit oriented development experiment?" Transportation Quarterly 56 (3).

Balz, V., and J. Schrijnen. 2009. "From concept to projects: Stedenbaan, The Netherlands " In TransitOriented Development edited by C. Curtis, J. Renne and L. Bertolini. Abingdon, Oxon, GBR Ashgate Publishing Group.

Belzer, D., and G. Autler. 2002. "Transit-oriented development: Moving from rhetoric to reality " The Brookings Institution Center on Urban and Metropolitan Policy Washington, D.C. .

Bernick, M., and R. Cervero. 1997. Transit villages in the 21st century New York, NY: McGraw-Hill.

Boarnet, M., and N. Compin. 1999. "Transit-Oriented Development in San Diego County: The Incremental Implementation of a Planning Idea " Journal of the American Planning Association 65 (1):80-95.

Burchell, R., D. Listokin, and C. Galley. 2000. "Smart Growth: More Than a Ghost of Urban Policy Past, Less Than a Bold New Horizon " Housing Policy Debate 11 (4):821-879.

Calthorpe, P. 1993. The next American metropolis New York, New York Princeton Architectural Press.

Cervero, R. . 2004. "The built environment and travel: evidence from the United States " European Journal of Transport and Infrastructure Research 2 (3):119-137. 
Cervero, R., C. Ferrell, and S. Murphy. 2002. Transit-oriented development and joint development in the United States: A literature review Transit Cooperative Research Program

Cervero, R., and K. Kockelman. 1997. "Travel demand and the 3Ds: density, diversity, and design " Transportation Research Part D: Transport and Environment 2 (3):199-219.

Chatman, D. 2008. "Deconstructing development density: quality, quantity, and price effects on household non-work travel " Transportation Research Part A: Policy and Practice 42 (7):10081030 .

Chatman, D. 2013. "Does TOD need the T?" Journal of the American Planning Association 79 (1):17-31.

Curtis, C., J. Renne, and L. Bertolini. 2009. Transit oriented development: Making it happen: Ashgate Publishing, Ltd.

Davison, G. 2011. "An unlikely urban symbiosis: Urban intensification and neighbourhood character in Collingwood, Vancouver." Urban Policy and Research 29 (02):105-124.

Dunphy, R., D. Myserson, and M. Pawlukiewicz. 2003. Ten Principles for Successful Development Around Transit. Washington, DC.: Urban Land Institute.

Dunphy, R., and D. Porter. 2006. "Manifestations of development goals in transit-oriented projects." Transportation Research Record: Journal of the Transportation Research Board 1977 (1):172178.

Dunphy, R. T. . 2005. "Shaping land use as if transportation mattered " UDP Annual Symposium on "Rethinking Growth Management" Washington, DC. .

Easly, G. V. . 1992. Staying inside the lines: urban growth boundaries Chicago, IL: American Planning Association

El-Geneidy, Ahmed, and David Levinson. 2006. Access to destinations: Development of accessibility measures. Citeseer.

Ewing, R., R. Pendall, and D. Chen. 2002. Measuring sprawl and its impacts Washington, DC. : Smart Growth America

Frank, L., and G. Pivo. 1994. "Impacts of mixed-use and density on utilization of three modes of travel: single-occupant vehicle, transit, and walking " Transportation Research Record (1466):44-52.

Geurs, K., K. Maat, P. Rietveld, and G. de Visser. 2012. "Transit-oriented development in the Randstad South Wing: goals, issues and research " Building the Urban Future and Transit Oriented Development Paris

Guerra, E., and R. Cervero. 2013. "Is a Half-Mile Circle the Right Standard for TODs? ." Access 17-21.

Handy, S. . 2001. "Local shopping as a strategy for reducing automobile travel " Transportation 28 (4):317-346.

Hansen, W. 1959. "How accessibility shapes land use." Journal of the American Institute of Planners 25 (2):73-76.

Headicar, P. . 2003. "The contribution of land use planning to reducing traffic growth: the English experience " European Journal of Transport and Infrastructure Research 3 (2):137-154.

Hofstad, H. . 2012. "Compact city development: High ideals and emerging practices " European Journal of Spatial Development

Jacobson, J., and A. Forsyth. 2008. "Seven American TODs: Good practices for urban design in TransitOriented Development projects." Journal of Transport and Land Use 1 (2):51-88.

Keller, J., G. Wulfhorst, T. Leysens, and A. L'Hostis. 2011. "Fostering rail-based accessibility by land management " European Transport Conference Glasgow, Scotland

Krizek, K. 2003. "Residential relocation and changes in urban travel: does neighborhood-scale urban form matter? ." Journal of the American Planning Association 69 (3):265-281.

Kuzmyak, R., and R. Pratt. 2003. Transit cooperative research program report 95. Washington DC. : Transportation Research Board

Langlois, M., D. van Lierop, R. Wasfi, and A. El-Geneidy. 2015. "Chasing sustainability: Do new TOD residents adopt more sustainable modes of transportation?" Transportation Research Board 94th Annual Meeting. 
Lund, H. . 2006. "Reasons for living in a transit-oriented development, and associated transit use " Journal of the American Planning Association 72 (3):357-366.

Maat, K. 2001. "Effects of the Dutch compact city policy on travel behavior " In Transport and

Environment: In Searn of Sustainable Solutions, edited by E. Feitelson and E. Verhoef, 208-230. United Kingdom: Edward Elgar Publishing.

Meurs, H., and R. Haaijer. 2001. "Spatial structure and mobility " Transportation Research Part D: Transport and Environment 6 (6):429-446.

Moudon, A., P. Hess, M. Snyder, and K. Stanilov. 1997. "Effects of site design on pedestrian travel in mixed-use, medium-density environments." Transportation Research Record (1578):48-55.

Nabielek, K. . 2012. "The compact city: Planning strategies, recent developments and future prospects in the Netherlands " AESOP 26th Annual Congress Ankara

Naess, P. 2003. "Urban structures and travel behavior: experiences from empirical research in Norway and Denmark " European Journal of Transport and Infrastructure Research 3 (2):155-178.

Naess, P., A. Strand, T. Naess, and M. Nicolaisen. 2011. "On their road to sustainability? The challenge of sustainable mobility in two Scandinavian capital regions " Town Planning Review 82 (3):285315.

Newman, P. 2007. "Planning for transit oriented development in Australian cities." BEDP Environment Design Guide.

Newman, P., and J. Kenworthy. 1999. Sustainability and cities: overcoming automobile dependence Washington, DC. : Island Press.

Newman, P., and J. Kenworthy. 2006. "Urban design to reduce automobile dependence." Opolis 2 (1):3551.

Niles, J., and D. Nelson. 1999. "Measuring the Success of Transit-Oriented Development." Retail Market Dynamics and Other Key Determinants, Prepared for the American Planning Association National Planning Conference, Seattle, Washington, April.

Ohland, G. . 2001. "Transit-oriented development in four cities " Partnership for Regional Liveability Conference Chicago, Illinois

Podobnik, B. 2002. "Assessing the social and environmental achievements of new urbanism: evidence from Orenco Station " Annual Meeting of the American Sociological Association San Francsico, California August, 82009.

Raman, S. . 2010. "Designing a liveable compact city: physical forms of city and social life in urban neighborhoods " Built Environment 36 (1):63-80.

Renne, J. 2008. "Smart growth and transit-oriented development at the state level: Lessons from California, New Jersey, and Western Australia." Journal of Public Transportation:77.

Renne, J. 2009. "From transit-adjacent to transit-oriented development " Local Environment: The International Journal of Justice and Sustainability 14 (1):1-15

Renne, J., and J. Wells. 2002. State of the literature: transit-oriented development. Voorhees Transportation Policy Institute

Renne, J., and J. Wells. 2004. "Emerging European-style planning in the USA: transit-oriented development." World Transport Policy \& Practice, 12-24.

Renne, J., J. Wells, A. Voorhees, and E. Bloustein. 2005. Transit-oriented development: developing a strategy to measure success. Transportation Research Board

Samuelson, M. . 2009. "Reducing Cars and Increasing Development: How the Creation of a Viable Transit Oriented Development Corridor in Aarlington, Virginia has Sparker Growth " Cities of the 21st Century 1 (1).

Scheurer, J., and A. Kroen. 2005. "A marriage of convenience? rail-supportive transport policies and urban consolidation in station precincts in Australia and Europe." State of Australian Cities Conference Brisbane, Australia

Seats2Meet. 2013. "Seats2Meet." 
Thomas, R., and L. Bertolini. 2014. "Beyond the case study dilemma in Urban Planning: Using a metamatrix to distil critical success factors in transit-oriented development." Urban Policy and Research.

Translink. 2010. Transit-oriented communities: a literature review on the relationship between the built environment and transit ridership Vancouver, B.C. .

Trudeau, D. 2013. "A typology of New Urbanism neighborhoods." Journal of Urbanism: International Research on Placemaking and Urban Sustainability 6 (2):113-138.

Tumlin, J., and A. Millard-Ball. 2003. "How to Make Transit-Oriented Development Work." Planning 69:14-19.

van Wee, B. , and K. Maat. 2003. "Land-use and transport: a review and discussion of Dutch research " European Journal of Transport and Infrastructure Research 3 (2):199-218.

Venner, M., and L. Ecola. 2015. "Financing transit-oriented development: Understanding and overcoming obstacles." Transportation Research Record: Journal of the Transportation Research Board.

Wayne, C. 2007. "Transforming a Bus Station into a Transit-Oriented Development: Improving Pedestrian, Bicycling, and Transit Connections." Transportation Research Record: Journal of the Transportation Research Board 2006:114-121. doi: doi:10.3141/2006-13. 